\title{
PELATIHAN MANAJEMEN KEUANGAN \\ SEBAGAI UPAYA MENINGKATKAN DAYA SAING UMKM KELURAHAN BENDA BARU PAMULANG
}

\author{
Gatot Kusjono'), Sunanto $^{2)}$, Diana Azwina ${ }^{3)}$, Tri Sulistyani4), Muhammad Andrei \\ Lesmono $^{5)}$ \\ 1,2,3,4,5 Program Studi Manajemen S1, Fakultas Ekonomi, Universitas Pamulang
}

\begin{abstract}
Abstrak
Kegiatan pengabdian kepada masyarakat bertujuan untuk mengadakan Pelatihan Manajemen Keuangan UMKM sebagai upaya meningkatkan daya saing bagi pelaku usaha kecil dan menengah di lingkungan Lembaga Pemberdayaan Masyarakat Kelurahan Benda Baru Pamulang Tangerang Selatan. Metode yang digunakan dalam pelatihan menggunakan metode pedampingan, diskusi, workshop dan bimbingan teknis (bimtek) pembuatan laporan keuangan sederhana. Hasil yang diperoleh selama pelatihan, secara keseluruhan kegiatan pelatihan meliputi: materi, fasilitator, tempat pelatihan, dan konsumsi mendapat respon sangat baik dari seluruh peserta dan sangat membantu dan bermanfaat bagi peserta pelatihan dalam menyusun manajemen keuangan yang baik serta dapat membantu meningkatkan ekonomi usaha kecil dan menengah di lingkungan LPM Benda Baru Pamulang.
\end{abstract}

Kata Kunci: Pelatihan, Manajemen, Keuangan, Daya Saing, UMKM.

\begin{abstract}
Community service activities aim to hold MSME Financial Management Training as an effort to increase competitiveness for small and medium business actors in the Community Empowerment Institution of Benda Baru Village, Pamulang, South Tangerang. The method used in the training uses the method of mentoring, discussions, workshops and technical guidance (bimtek) for making simple financial reports. The results obtained during the training, overall training activities include: material, facilitators, training places, and consumption received a very good response from all participants and are very helpful and useful for training participants in compiling good financial management and can help improve the economy of small businesses and medium in LPM Benda Baru Pamulang.
\end{abstract}

Keywords: Training, Management, Finance, Competitiveness, UMKM. 


\section{PENDAHULUAN}

\subsection{Analisis Situasi Permasalahan}

Dalam kegiatan Pengabdian Kepada Masyarakat kami melakukan kerjasama dengan Lembaga Pemberdayaan Masyarakat (LPM) di Kelurahan Benda Baru Pamulang Tangerang Selatan. Dimana tugas dan fungsi dari LPM adalah meningkatkan Sumber Daya Manusia dalam mengawal proses pembangunan khususnya di Benda Baru. Benda Baru yang mempunyai 24 Rukun warga dan 157 Rukun Tetangga. LPM tidak hanya mengawasi infrastruktur dan pembangunan tapi juga SDM harus ditingkatkan. LPM dalam merencanakan pengawasan secara bersama sama dengan pemerintah, sebelumnya LPM melakukan diskusi dengan tokoh maysarakat, lembaga, organisasi dan masyarakat di wilayahnya. LPM memiliki peran aktif karena pengurus LPM berada ditingkat kelurahan yang mengetahui kondisi masing masing daerahnya. LPM berdiri di atas inisiatif masyarakat yang tugasnya adalah bersama sama dengan pemerintah di tingkat kelurahan dan tingkat kecamatan untuk mengawal pembangunan yang ada dilingkungan masing masing.

Pelaksanaan PKM kali ini terjadi pada saat Pembatasan Sosial Berskala Besar (PSBB) dalam memutus rantai penularan pandemi Corvid 19. Sejak pertama diberlakukannya masa Pembatasan Sosial Berskala Besar (PSBB) yaitu tanggal 18 April 2020 (NOMOR HK.01.07 / MENKES / 249 / 2020) hingga saat ini masih terdapat celah dan kelonggaran di lapangan selama PSBB berlangsung. Sehubungan dengan hal itu, maka ditetapkanlah keputusan Gubernur Banten no 443/kep.161.Huk/2020 dan Peraturan Walikota No 338/Kep 163.Huk/2020 tentang penetapan Perpanjangan pelaksanaan PSBB yang sudah sampai pada fase ke tiga di Tangerang Selatan ini.

Pembatasan kegiatan social ini, tentunya sangat berdampak untuk warga yang kesehariannya sebagai pedagang baik skala mikro sampai menengah, pegawai pemerintah, karyawan swasta, dan pelayanan jasa yang penghasilannya didapatkan dengan cara bertemu langsung dengan para konsumen atau kliennya. Oleh karenanya, adanya pelatihan manajemen keuangan diharapkan dapat memberikan bekal pengetahuan yang memadai bagi pelaku usaha, selanjutnya dapat mengimplementasikan ke dalam usaha nyata yang ditekuni. Sehingga membantu pengembangan UMKM dalam meningkatkan kemampuan ekonomi keluarga dan masyarakat.

\subsection{Permasalahan}

Dari hasil survey dan wawancara dengan Ketua LPM bahwa permasalahan yang ada saat ini dan masih berlanjut, salah satunya yaitu pedagang mikro dan kecil atau UMK, pegawai yang dirumahkan, warga dengan pendididikan yang rendah, warga dengan penghasilan yang minim ataupun tidak ada pemasukan lagi, masih banyak yang belum paham tentang PSBB dan masih terjadi pelanggaran protap kesehatan dalam pencegahan Corvid 19. Solusi yang diberikan terhadap permasalahan oleh LPM adalah perlu adanya penyuluhan tentang bagaimana meningkatkan pendapatan dan menyusun manajemen keuangan yang baik sebagai upaya meningkatan daya saing bagi para usaha mikro dan kecil. Dengan 
menjadikan protap kesehatan menjadi perilaku sehari hari warga supaya selain membantu perekonomian di wilayahnya, juga mengurangi penderita positif Corvid 19. Selain itu, perlu dilakukan penyemporotan di daerah yang dirasakan rawan terhadap penyebaran Corvid 19.

\subsection{Tujuan Pengabdian kepada Masyarakat}

1). Memberdayakan sumber daya manusianya,

2). Membantu LPM meningkatkan UMKM dan pengawasan sehingga UMKM dapat meningkatkan penghasilannya dan mencukupi kebutuhannya,

3). Memberikan pengetahuan tentang manajemen keuangan yang baik untuk mengembangkan usaha

4). Memberikan pelatihan untuk membuat laporan keuangan, serta miningkatkan kesadaran warga dalam menjalankan protap kesehatan untuk mencegah penularan virus CORVID 19 dan menjadi perilaku sadar bersih dan sadar sehat sehingga kita dapat memutus masa PSBB den memasuki era new normal.

\subsection{Kerangka Pemecahan Masalah}

Alur kerja yang digunakan dalam menyelesaikan permasalahan yang dihadapi UKM di kelurahan benda baru Pamulang seperti ditunjukkan pada gambar berikut:

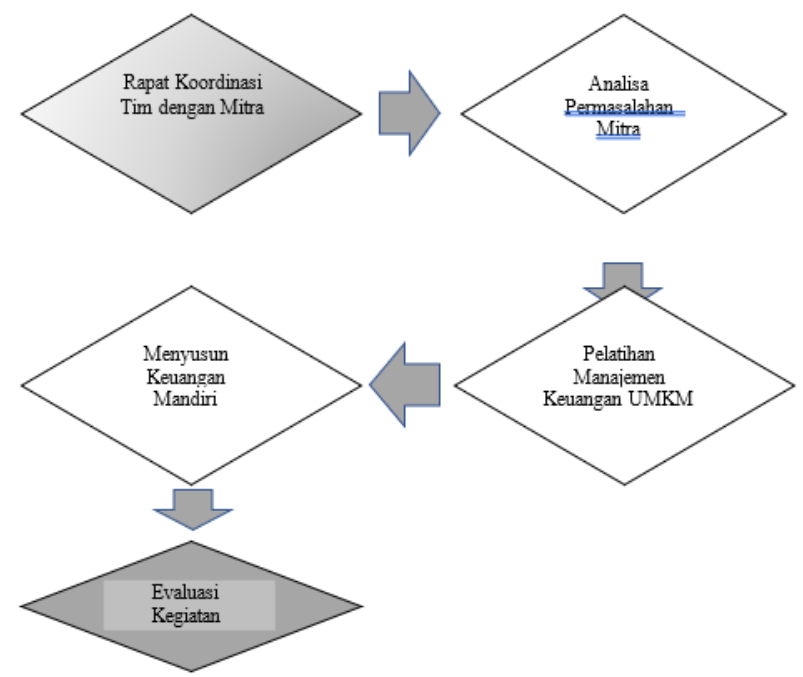

Gambar 1 Alur Pelatihan Penyusunan Laporan Keuangan UMKM

Berdasarkan alur pada gambar di atas, ada tiga tahapan yang harus dilakukan dalam program pembuatan jurnal pendidikan. Tiga tahapan yang dilakukan meliputi:

1). Tahap Analisa Permasalahan Mitra

2). Tahap Pelatihan Manajemen Keuangan

3). Tahap Menyusun Laporan Keuangan Mandiri

\subsection{Realisasi Pemecahan Masalah}

Realisasi pemecahan masalah dalam pelatihan manajemen kuangan UKM Kelurahan Benda Baru Pamulang, Kota Tangerang Selatan, dilaksanakan menggunakan tiga tahapan sebagai berikut: 
1). Tahap Pra Pelatihan

Kegiatan pra pelatihan ini dilakukan dengan koordinasi dengan mitra berkaitan dengan tujuan untuk menggali permasalahan-permasalahan yang dihadipi oleh mitra serta mencaraikan solusi terbaik berdasarkan kondisi mitra.

2). Tahap Pelatihan

Kegiatan pelatihan/workshop merupakan kegiatan sosialisasi dan penyampaian materi tentang manajemen keuangan sederhana yang harus dipersiapkan oleh usaha kecil dan menengah. Sehingga kendala yang dihadapi dalam perkembangan usaha yang dirintisnya dapat dijadikan solusi dan jalan keluar pemecahananya. Selain itu peserta pelatihan akan diajarkan menyusun laporan keuangan sederhana berdasarkan usaha yang sudah dirintisnya.

3). Tahap Pasca Pelatihan

Pada tahap ini, fokus kegiatan yang dilakukan dengan melakukan monitoring hasil pelaksanaan pelatihan bagi usaha mikro dan menengah, serta menyusun program lanjutan yang diperlukan untuk pengembangan usaha.

\subsection{Kajian Pustaka}

\subsubsection{Pengelolaan Keuangan UMKM}

Menurut Phobi Kevin dalam Baskoro (2014), ada lima tips yang harus diperhatikan dalam pengelolaan keuangan usaha menyampaikan lima tips dalam pengelolaan keuangan usaha. 5 (lima) tips tersebut antara lain:

1). "Perlunya pemisahan antara keuangan usaha dan keuangan pribadi;

2). Menentukan besarnya persentase keuangan yang akan untuk kebutuhan usaha;

3). Melakukan pencatatan keuangan (pembukuan) secara tertib untuk mengontrol semua transaksi keuangan, baik itu pemasukan maupun pengeluaran, serta utang dan piutang;

4). Mengurangi risiko dari utang usaha;

5). Mengendalikan kelancaran arus kas usaha."

Sebagai pelaku usaha hendaknya memperhatikan lima tips tersebut dan tidak boleh mengabaikannya. Pengelolaan manajemen keuangan merupakan aspek penting yang harus diperhatikan dan tidak boleh diabaikan. Karena dengan pengelolaan yang baik, maka perkembangan usaha juga akan dapat diketahui dengan baik. Apakah usaha yang dilakukannya dapat berkembang atau tidak.

\subsubsection{Laporan Keuangan}

Laporan keuangan merupakan hal yang sangat penting dilakukan bagi pelaku usaha baik skala kecil, mikro dan menengah. Catatan keuangan ini sangat diperlukan bagi pelaku usaha untuk mengetahui perkembangan usaha yang dirintisnya. Apakah usaha yang dirintis tersebut dapat berkembang dengan baik atau tidak. Laporan keuangan tersebut juga dapat digunakan untuk mengukur kinerja usaha yang dirintisnya dan juga bisa digunakan 
dalam pengambilan kebijakan ke depannya. Saangat disayangkan sebagian besar pelaku UMKM masih mengesampingkannya. Hal ini dikarenakan pembuatan laporan tersebut dianggap cukup rumit dan memakan waktu. Padahal, banyak contoh sederhana dalam membuat laporan keuangan yang bias dijadikan panduan.

Berikut ini bentuk sederhana laporan keuangan yang bisa dibuat oleh pelaku UMKM.

1). Membuat Buku Catatan Pengeluaran

Buku catatan ini digunakan untuk mencatat semua pengeluaran dengan jelas, mulai dari pembelian barang hingga pengeluaran. Tujuannya untuk mengetahui jumlah keseluruhan modal usaha yang telah dikeluarkan.

2). Membuat Buku Catatan Pemasukan

Buku ini mencatat semua hal yang berhubungan dengan pemasukan uang dengan jelas. Termasuk hasil penjualan barang sampai piutang yang sudah dibayarkan. Tujuan pencatatan ini untuk memudahkan dalam meyusun laporan bulanan.

3). Membuat Buku Kas Utama

Buku kas utama merupakan gabungan antara catatan pemasukan dan pengeluaran. Penggabungan ini dimaksudkan untuk mengetahui lebih datail lagi keuntungan atau kerugian usaha. Selain itu dengan adanya buku kas ini bias dijadikan perencanaan strategis usaha ke depannya.

4). Buku Stok Barang

Buku stok barang ini digunakan untuk mencatat arus keluar dan masuk barang setiap harinya. Jika penjualan produk usaha tinggi, maka jumlah barang yang keluar dan masuk juga tinggi. Selain itu buku ini juga bias digunakan untuk memonitor jumlah persedian barang yang dimiliki.

5). Buku Inventaris Barang

Buku inventaris digunakan untuk mencatat semua barang yang dimiliki, baik barang yang sudah digunakan maupun barang dibeli. Buku ini juga merupakan asset dari usaha yang dijalankan.

\subsubsection{Pentingnya Laporan Keuangan}

Menurut Akifa (2013: 9-10) pentingnya laporan keuangan sangat diperlukan untuk:

1). "Mengetahui segala macam informasi keuangan perusahaan selama kurun waktu tertentu, baik satu bulan, enam bulan, ataupun satu tahun. Informasi keuangan tersebut bisa berupa:

a. Perubahan aset perusahaan, pertambahan/pengurangan utang perusahaan, dan pertambahan/pengurangan modal perusahaan;

b. Pertumbuhan/kemerosotan ekonomi perusahaan dari bulan ke bulan atau tahun ke tahun;

c. Jenis-jenis aset yang dimiliki, mulai dari gedung, tanah, kendaraan, dan aset cabang;

d. Jenis-jenis utang yang dimiliki, mulai dari utang kepada kreditor 1, kreditor 2, kreditor 3, dan sebagainya; serta 
e. Jenis-jenis modal yang dimiliki, mulai dari modal saham, modal tetap, modal lancar dan sebagainya.

2). Mengetahui kondisi perusahaan saat itu; apakah perusahaan sedang dalam keadaan sehat, mengalami krisis, atau sudah dinyatakan bangkrut.

3). Mengetahui seberapa lama perusahaan dapat bertahan dari krisis dan bangkit dari kebangkrutan, atau malah sebaliknya".

\section{METODE PELAKSANAAN}

Khalayak sasaran dalam pengabdian kepada masyarakat yaitu Ibu-ibu PKK, pelaku usaha dan generasi muda di lingkungan Rw.6, Rw.10 dan Rw.12 Kelurahan Benda Baru Pamulang yang berjumlah 25 orang peserta. Adapun waktu pelaksanaan pada hari Sabtu dan Ahad, tanggal 14-15 November 2020, bertempat di Aula Al Falah V, Benda Baru Pamulang..

Metode yang digunakan dalam pelatihan manajemen keuangan usaha mikro dan menengah Keluarahan Benda Baru, Pamulang, Kota Tangerang Selatan, menggunakan metode pedampingan, diskusi, workshop dan bimbingan teknis (bimtek) Pembuatan Laporan Keuangan Sederhana.

\section{1). Metode Pelaksanaan Dalam Bidang Pengajaran}

Metode pendekatan pada program yang akan dilaksanakan adalah :

a. Melakukan pendataan pada mitra sampai sejauh mana pemahaman mitra tentang pembukuan / akuntansi sehingga dapat diketahui kondisi tentang pengetahuan mitra mengenai usaha yang dijalankannya.

b. Melakukan pengajaran pertama berupa teori tentang dasar-dasar akuntansi sederhana dan bagaimana penyusunan laporan keuangan yang baik

c. Melakukan pengajaran kedua berupa teori dasar dasar akuntansi/manajemen keuangan untuk UMKM, bagaimana me-nyelenggarakan akuntansi bagi UMKM dan membuat laporan keuangan bagi usahanya.

d. Mitra diberikan pendampingan dalam mempraktikkan menyusun laporan keuangan usahanya.

\section{2). Metode Pelaksanaan Dalam Bidang Manajemen}

a. Berkoordinasi dengan mitra untuk proses belajar mengajar

b. Pembagian jadwal untuk proses belajar mengajar

c. Membuat tugas kepada mitra untuk menerapkan pengetahuan yang dimiliki dalam menyusun laporan keuangan usaha yang digelutinya.

\section{3). Metode Pelaksanaan Dalam Bidang Pemasaran}

a. Dengan pengetahuan yang dimiliki oleh mitra tentang pembukuan (akuntansi) usahanya diharapkan mitra mampu menggunakan laporan keuangannya sebagai sarana untuk pengambilan keputuan terutama untuk meningkatkan kapasitas usahanya khususnya dalam hal peningkatan penjualannya melalui pembelajaran analisa laba dan biaya.

b. Mampu menyusun laporan keuangan dan menyajikannya dalam bentuk proposal kepada lembaga keuangan (perbankan) dalam rangka memperoleh pembiayaan.

c. Mampu membukukan usahanya dan mengetahui posisi keuangan usahanya. 


\section{HASIL DAN PEMBAHASAN}

\subsection{Hasil}

Hasil pelaksanaan PKM diukur berdasarkan jawaban peserta pelatihan dengan tentang: materi pelatihan, fasilitator, tempat pelatihan dan sajian/konsumsi selama pelatihan yang diukur menggunakan penilaian skala 1 sampai 5 berikut:

Tabel 1 Skala jawaban responden pelatihan

\begin{tabular}{cl}
\hline \multicolumn{1}{c}{ Skor } & Kriteria \\
\hline $4,21-5,00$ & Sangat Baik \\
\hline $3,41-4,20$ & Baik \\
\hline $2,61-3,40$ & Cukup \\
\hline $1,81-2,60$ & Kurang \\
\hline $1,00-1,80$ & Kurang Skali \\
\hline
\end{tabular}

Tabel 2 Penilaian Responden Terhadap Pelaksanaan Pelatihan

\begin{tabular}{|c|c|c|c|c|c|c|c|c|c|c|}
\hline No & Penilaian Kegiatan & 5 & 4 & 3 & 2 & 1 & Jmh & Skor & $\begin{array}{c}\text { Rata- } \\
\text { rata }\end{array}$ & Keterangan \\
\hline A & Materi Pelatihan & & & & & & & & & \\
\hline 1 & Jelas dan mudah diikuti & 13 & 4 & 2 & 0 & 0 & 19 & 87 & 4.58 & Sangat Baik \\
\hline \multirow[t]{2}{*}{2} & $\begin{array}{l}\text { Relevan dengan objektivitas } \\
\text { pelatihan }\end{array}$ & 12 & 5 & 2 & 0 & 0 & 19 & 86 & 4.53 & Sangat Baik \\
\hline & Sub Total_1 & 25 & 9 & 4 & 0 & 0 & 38 & 173 & 4.55 & Sangat Baik \\
\hline B & Fasilitator & & & & & & & & & \\
\hline 1 & Penguasaan materi & 13 & 4 & 2 & 0 & 0 & 19 & 87 & 4.58 & Sangat Baik \\
\hline 2 & Gaya penyampaian & 12 & 5 & 2 & 0 & 0 & 19 & 86 & 4.53 & Sangat Baik \\
\hline 3 & Kejelasan dalam penyampaian & 10 & 7 & 2 & 0 & 0 & 19 & 84 & 4.42 & Sangat Baik \\
\hline 4 & $\begin{array}{l}\text { Kemampuan dalam menjawab } \\
\text { pertanyaan }\end{array}$ & 13 & 4 & 2 & 0 & 0 & 19 & 87 & 4.58 & Sangat Baik \\
\hline \multirow[t]{2}{*}{5} & Penampilan & 12 & 4 & 3 & 0 & 0 & 19 & 85 & 4.47 & Sangat Baik \\
\hline & Sub Total_2 & 60 & 24 & 11 & 0 & 0 & 95 & 429 & 4.52 & Sangat Baik \\
\hline $\mathbf{C}$ & Tempat Pelatihan & & & & & & & & & \\
\hline \multirow[t]{2}{*}{1} & Kenyamanan dalam belajar & 10 & 7 & 2 & 0 & 0 & 19 & 84 & 4.42 & Sangat Baik \\
\hline & Sub Total_2 & 10 & 7 & 2 & 0 & 0 & 19 & 84 & 4.42 & Sangat Baik \\
\hline D & Sajian/Konsumsi & & & & & & & & & \\
\hline 1 & Coffe break/snack & 11 & 4 & 4 & 0 & 0 & 19 & 83 & 4.37 & Sangat Baik \\
\hline \multirow[t]{3}{*}{2} & Makan Siang & 9 & 3 & 7 & 0 & 0 & 19 & 78 & 4.11 & Baik \\
\hline & Sub Total_2 & 20 & 7 & 11 & 0 & 0 & 38 & 161 & 4.24 & Sangat Baik \\
\hline & Kesimpulan Umum Pelatihan & 115 & 47 & 28 & 0 & 0 & 190 & 847 & 4.46 & Sangat Baik \\
\hline
\end{tabular}

Berdasarkan hasil jawaban 19 responden dari 25 peserta pelatihan pada tabel di atas, diperoleh hasil sebagai berikut:

1). Materi pelatihan yang meliputi kejelasan materi, mudah diikuti dan relevan dengan obyektivitas pelatihan yang dilaksanakan diperoleh skor nilai 4,55 dengan kriteria sangat baik karena terletak diantara skor 4,21 sampai 5,00.

2). Fasilitator pelatihan dalam hal penguasaan materi, gaya penyampaian, kejelasan materi, penampilan dan kemampuan menjawab pertayaan peserta 
diperoleh skor nilai 4,52 dengan kriteria sangat baik karena terletak diantara skor 4,21 sampai 5,00 .

3). Tempat pelatihan dalam hal ini kenyamanan peserta selama peserta mengikuti pelatihan tergolong sangat baik dengan skor nilai 4,42 dan terletak diantara skor 4,21 sampai 5,00.

4). Sajian/konsumsi dalam hal penyediaan coffee break/snak dan makan siang peserta diperoleh skor nilai 4,24 dengan kriteria sangat baik karena terletak diantara skor 4,21 sampai 5,00.

Dari hasil keseluruhan pelaksanaan pelatihan manajemen keuangan bagi usaha kecil dan menengah rata-rata keseluruhan diperoleh nilai 4,46 katagori pelatihan "sangat baik". Adapun urutan evaluasi pelaksanaan kegiatan pelatihan dari yang tertinggi hingga terendah meliputi: materi pelatihan skor 4,55, fasilitator dengan skor 4,52, tempat pelatihan dengan skor 4,42 dan sajian/konsumsi dengan skor 4,24.

\section{Pembahasan}

1). Materi pelatihan yang diberikan kepada peserta sangat baik karena materi disampaikan dengan jelas, mudah diikuti dan relevan dengan peserta.

2). Fasilitator pelatihan dangat baik dalam menguasai materi, cara/gaya penyampaian, kejelasan materi, penampilan dan kemampuan dalam menjawab permasalahan yang disampaikan oleh peserta.

3). Tempat pelatihan sangat baik, karena peserta merasa nyaman dalam mengikuti seluruh kegiatan pelatihan dari awal sampai akhir.

4). Konsumsi dan coffe break/snak yang disediakan sangat baik.

Adapun dokumentasi kegiatan pengabdian masyarakat seperti ditunjukkan pada gambar berikut:
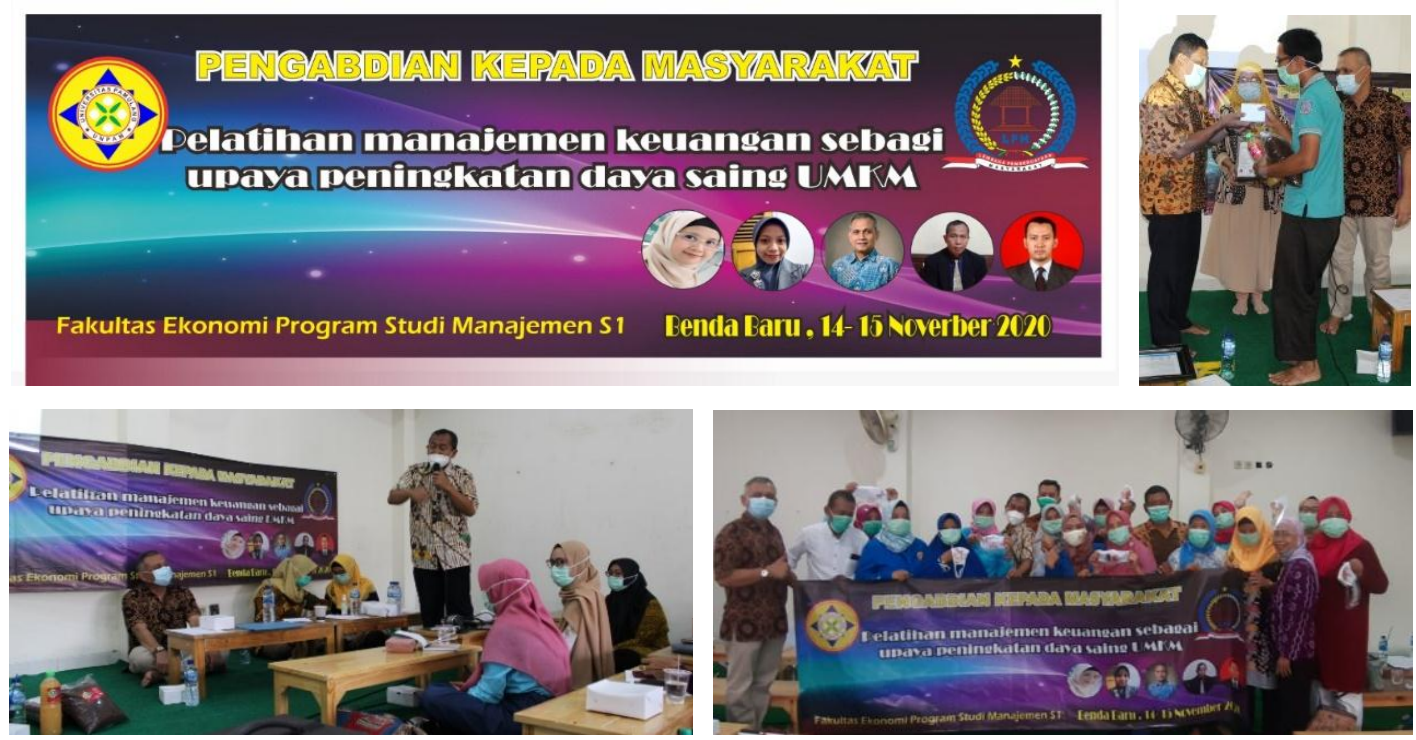

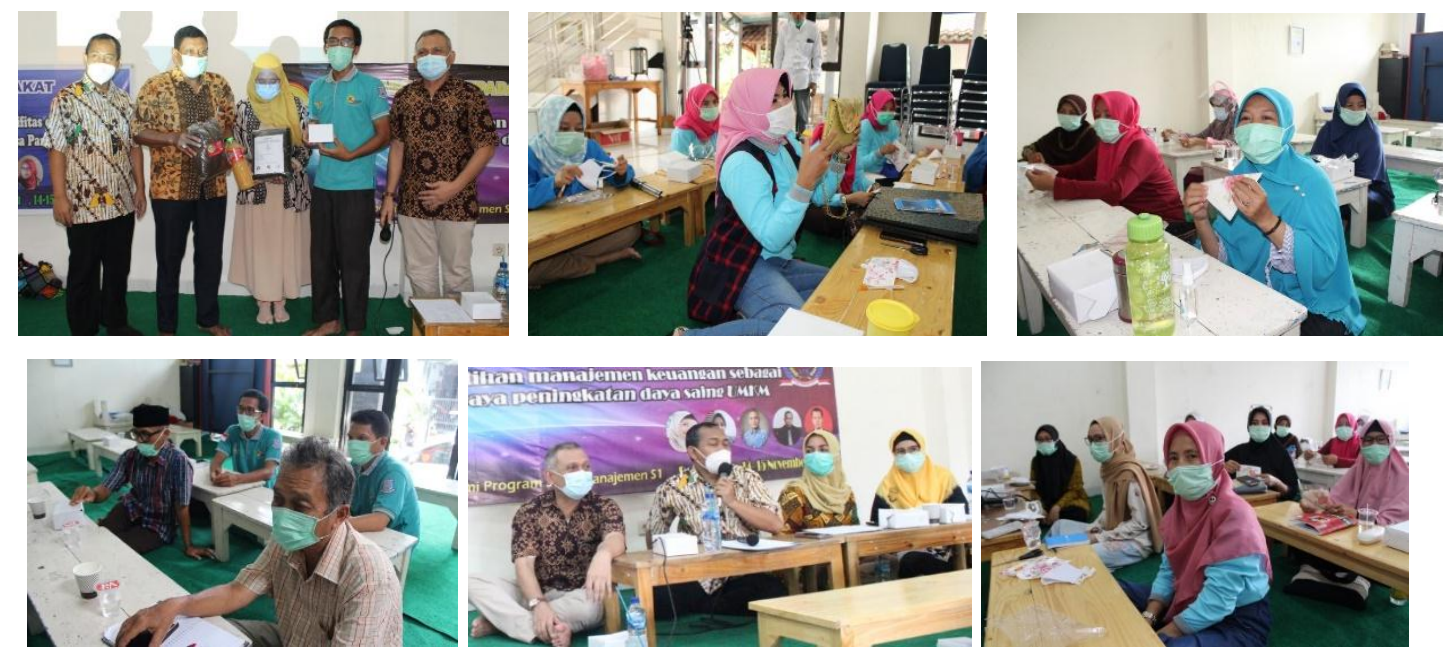

Gambar 2 Foto Kegiatan Pengabdian Masyarakat

\section{SIMPULAN}

Kegiatan pengabdian kepada masyarakat yang dilakukan di lingkungan RW.6, RW.10 dan RW 12 Lembaga Pemberdayaan Masyarakat (LPM) Benda Baru, Pamulang - Kota Tangerang Selatan, sangat bermanfaat bagi masyarakat dalam meningkatkan kemampuan ekonomi keluarga dalam masa pandemi Covid 19. Oleh karena itu, kegiatan sejenis dapat dilaksanakan secara berkelanjutan dengan menggali potensi produk-produk yang dapat dikembangkan di lingkungan masyarakat sekitar Kelurahan Benda Baru. Selain itu diperlukan adanya bantuan solusi untuk membantu pemasaran produk yang dihasilkan, agar dikenal dan dikonsumsi oleh masyarakat luas, sehingga akan meningkatkan ekonomi masyarakat menjadi lebih baik lagi.

Secara keseluruhan kegiatan pelatihan yang meliputi: materi, fasilitator, tempat pelatihan, dan konsumsi mendapat respon sangat baik dari seluruh peserta. Sehingga pelatihan sejenis dapat terus dilaksanakan untuk membantu meningkatkan ekonomi usaha kecil dan menengah di lingkungan LPM Benda Baru Pamulang.

Adapun saran - saran yang perlu dipertimbangkan yaitu perlu adanya pelatihan berkelanjutan bagi masyarakat di lingkungan Kelurahan Benda Baru Pamulang dengan beberapa masukan peserta pelatihan:

1). Jumlah peserta diperbanyak.

2). Kegiatan pelatihan sering dilaksanakan.

3). Materi yang diberikan lebih bervariasi, meliputi pelatihan keterampilan, makanan, membatik maupun menganyam.

4). Waktu pelatihan bias ditambah/diperpanjang.

\section{DAFTAR PUSTAKA}

Abdulloh Mubarok, M. Faqihudin. (2011). Pengelolaan Keuangan untuk Usaha Kecil dan Menengah. Yogjakarta : Penerbit Suluh Media. 
Addi M Idhom. (2020). Update Corona 29 Mei 2020 di Indonesia \& Data Pandemi Dunia Terkini. https://tirto.id/update-corona-29-mei-2020-di-indonesia-data-pandemidunia-terkini-fDD5, di akses tanggal 27 Oktober 2020

Admin Keu LSM. (2013). Pengelolaan Keuangan Bagi UMKM. Diakses pada 27 Oktober 2020. http://keuanganlsm.com/pengelolaan-keuangan-bagi-ukm/

Akifa P. Nayla. (2013). Cara Praktis Menyusun Laporan Keuangan. Yogjakarta : Penerbit Laksana.

Amir Solihin, Muhammad dan Sudirja, Rija. (2007). Pengelolaan Sumber Data Alam Secara Terpadu Untuk Meperkuat Perekonomian Lokal

Faisal Maliki Baskoro. (2014). Lima tips cerdas mengelola keuangan UMKM. http://www.beritasatu.com/ekonomi/173156-lima-tips-cerdas-mengelolakeuangan-umkm.html Diakses pada 27 Oktober 2020

Peraturan Gubernur Banten no 443/kep.161.Huk/2020 tentang Pedoman PSBB

Sony Warsono, dkk. (2010). Akuntansi UMKM Ternyata Mudah Dipahami dan Dipraktikkan. Yogyakarta: Asgard Chapter.

Surat Edaran dari Menteri Pendidikan dan Kebudayaan Nomor: 36962/MPK.A/HK/2020 tertanggal 17 Maret 2020 tentang Pembelajaran secara Daring dan Bekerja dari Rumah dalam rangka Pencegahan Penyebaran Corona Virus Disease (Covid-19);

Surat Keputusan Menteri Kesehatan Nomor HK.01.07 /Menkes/249/2020, tentang Penetapan Pembatasan Sosial Berskala Besar di Wilayah Provinsi BANTEN Dalam Rangka Percepatan Penanganan Corona Virus Disease 2019 (COVID 19);

Widia Pangestika. (2019). 7 Strategi Bisnis untuk Bersaing di Era Digital. https://www.jurnal.id/id/blog/strategi-bisnis-untuk-bersaing-di-era-digital/, $\quad$ di akses tanggal 27 Oktober 2020. 